\title{
ERASMO, BARBARI, INDOCTE DOCTI E CICERONIANI: OS MODELOS CLÁSSICOS E O ENSINAMENTO CRISTÃO
}

\author{
Elaine Cristine SARTORElli \\ FERNANDo Gorab LEME
}

Universidade de São Paulo (USP)

\begin{abstract}
Resumo. O propósito deste trabalho é comentar a importância e a permanência dos autores da Antiguidade clássica na obra de um autor cristão consciente dos problemas dessa convivência, o humanista Erasmo de Rotterdam. Este, sem jamais ter abandonado a defesa dos estudos bíblicos, defendeu, por outro lado, a aquisição de um conhecimento profundo dos autores clássicos. No contexto da literatura cristã, em que palavras idealmente rudes devem ser capazes de expressar verdades sublimes, essa questão forma o pano de fundo para discussões sobre o papel da eloquência numa época em que as polêmicas religiosas lançam novas suspeitas sobre a ars, ao mesmo tempo em que a obriga a novas práticas. Esse tema perpassou toda a obra de Erasmo e foi o centro de várias das polêmicas em que se envolveu, tanto contra os barbari, que são aqueles que abrem mão da leitura das obras da antiguidade clássica, quanto contra os ciceroniani, que são aqueles que desprezam os temas cristãos para dedicar-se à literatura pagã.
\end{abstract}

Palavras-chave. Renascimento, retórica, Erasmo, antiguidade clássica, cristianismo.

Aquilo a que chamamos Renascimento parece só ter Sido possível De fato pela soma de dois fatores: o reaparecimento de muitos textos antigos e sua consequente disseminação e popularização, a qual se deu como decorrência do surgimento de uma nova tecnologia, a prensa de Gutenberg. Movidos pela possibilidade, absolutamente nova, de divulgar seus livros numa escala jamais imaginada antes, estudiosos da época entregaram-se fervorosamente ao estudo dos clássicos antigos, o qual se tornou "parte central e inseparável da educação humanística". ${ }^{1}$ Duas coisas devem ser consideradas neste momento. A primeira é que estes homens que se dedicaram com tanto afinco à promoção de autores pagãos eram não apenas cristãos por nascimento e formação, mas também, em grande maioria, membros do 
clero. Em segundo lugar, é preciso ter em conta que esse movimento foi, em uma medida de que talvez não nos apercebamos hoje, um movimento essencialmente latino, ou seja, em língua latina. Humanistas, mesmo os helenistas, escreviam sobretudo em latim, e foi em latim que Pico della Mirandola, por exemplo, divulgou Platão. Assim sendo, quando falamos aqui em imitatio, elocutio etc., estamos sempre falando da língua latina.

Dito isso, temos três "camadas", por assim dizer, de língua latina que temos de levar em conta nesse período em que os textos antigos redescobertos começam a conviver com o corpus christianum.

A primeira é aquela de que os polemistas da época patrística lançaram mão, ou seja, o latim da Vulgata, o sermo humilis cristão. Naquele momento, em que o Cristianismo se definiu em relação ou oposição à "filosofia pagã", uma presumida e alegada ausência de retórica passou a ser tida como condição de verdade absoluta. ${ }^{2}$ Assim, o "advogado de Cristo" era aquele que falava a língua "simples e pura" das Escrituras, enquanto que aqueles que se preocupavam com a ornamentação eram caracterizados como "falsos mestres", os quais, como os sofistas, só podiam estar ocultando suas heresias por meio de subterfúgios próprios da tergiversação e da sedução. Faz-se assim o elogio de um gênero rude e cru que afirma prescindir da ornamentação, sine tropo et sine sophismate, visto e entendido como aquele que serve mais perfeitamente à veiculação de uma verdade, a Verdade, que lhe é externa (e não constituída no discurso e pelo discurso, à maneira aristotélica). A alegação é que, se o Espírito Santo não usou de artifícios retóricos para falar, mas antes, ao contrário, preferiu as palavras simples e comuns, assim também o porta-voz da mensagem não deveria se esforçar para falar bem segundo os procedimentos retóricos, considerados sofísticos em bloco, mas sim dizer aquilo que tinha sido enviado a dizer, sem rebuscamentos ou preocupações voltadas para o deleite, de modo que a percepção corrente era a de que "a linguagem é principalmente um meio para a confissão, uma ferramenta para o pregador e para o pastor e não um ornamento para o poeta". ${ }^{3}$

Uma segunda camada é aquela herdada da Escolástica medieval, na qual a lógica predominou sobre a ornamentação do discurso. Havia, nas disputationes, um formato rígido para perguntas e respostas, e, assim, os debatedores não visavam a sobressair-se pela oratória. Não havia tampouco a preocupação de adaptar o discurso aos ouvintes nem a da ornamentação ligada à função do delectare. Os discursos eram, portanto, praticamente monocórdios; solidamente estruturados, mas monótonos. 
Esse tipo de texto está exemplarmente mostrado na Summa theologica de Tomás de Aquino, em que 512 questões estão subdividas em 2.669 capítulos. Tome-se como exemplo o seguinte passo: "portanto, dentre as virtudes teologais, devemos tratar primeiro da fé; segundo, da esperança; terceiro, da caridade. Ora, sobre a fé, há quatro considerações a fazer. Primeiro, sobre a fé em si mesma. Segundo, sobre os dons da inteligência e da ciência, que lhe correspondem. Terceiro, dos vícios opostos. Quarto, dos preceitos pertencentes a esta virtude.

Quanto à fé, devemos tratar primeiro do seu objeto; segundo, do seu ato; terceiro, do hábito mesmo da fé. Na primeira questão, tratam-se dez artigos: (1) se o objeto da fé é a verdade primeira; (2) se o objeto da fé é algo de complexo; (3) se a fé é suscetível de falsidade", e assim por diante. A forma típica e praticamente fixa desse tipo de argumentação é an sit.

Quanto aos estudos de retórica em si, tal como concebidos no trivium medieval, estes pouco têm a ver com definições como as de Cícero, que relacionavam a retórica com a vida pública e pouco significavam em uma "sociedade conturbada por invasões ou que se reorganizava sob o feudalismo". ${ }^{4}$ Desse modo, a retórica havia perdido gradativamente seu lugar para os estudos da lógica; o que dela restava concentrava-se especialmente no ornatus. No século XIII, por exemplo, o autor francês Alain de Lille descreve em seu Anticlaudianus uma alegoria para as artes liberais: elas dariam uma carruagem para a Prudentia em sua busca pelo bem humano. A gramática lhe dá as bases; a lógica, os eixos que as unem; o quadrivium, as rodas que a faz andar. Quanto à retórica, esta apenas adorna a carruagem com pedras preciosas e ouro. ${ }^{5}$

Nesse contexto de mescla de uma já desde há muito tradicional "retórica anti-retórica" cristã, usada especialmente em polêmicas, e de uma herança dialético-escolástica, surge uma "novidade": a oratória persuasiva e convenientemente ornada dos antigos por que os humanistas se apaixonaram. Assim, a terceira camada de que vamos tratar é precisamente aquela que nos faz nomear aquela época como Renascimento, ou seja, como uma era em relação com outra que lhe antecedeu e a que procurou imitar, a Antiguidade clássica. Nesse momento, um nome se impôs sobre todos os outros, um nome cujo peso e influência foram tais que uma controvérsia sobre sua eleição como modelo único para imitação marcou profundamente a retórica do século xvi como um todo. Esse nome era Cícero.

${ }^{4}$ Baldwin 1928, 142.

5 Idem, 173. 
Petrarca, por exemplo, hoje universalmente reconhecido por seus versos em italiano, foi também um entusiasta do orador romano. Deve-se a ele a redescoberta de dois discursos, as Cartas a Ático e a Quinto, bem como a correspondência com Bruto. ${ }^{6}$ Posteriormente, por volta de 1417 , deu-se a recuperação completa do De Oratore. Iniciam-se a partir de então as chamadas "controvérsias ciceronianas", em que se envolveram todos os principais nomes do Renascimento: Lorenzo Valla e Poggio Bracciolini, Angelo Poliziano e Paolo Cortesi, Pico della Mirandola e Pietro Bembo, Calcagnini e Cinzio. Como veremos a seguir, também Erasmo escreveu uma sátira contra os "ciceronianos", o Dialogus Ciceronianus. ${ }^{7}$

\section{BARBARI E CICERONIANI}

A consciência de que houve uma Idade Média que separava os humanistas da Antiguidade começou a se delinear em Petrarca, mas só se estabeleceu claramente com Lorenzo Valla. Foi ele o primeiro a afirmar com clareza a ideia de que um longo período afastava seus contemporâneos da Antiguidade clássica; e que esse período fora "bárbaro". Antiguidade (e o renascimento desta) e barbárie são, pois, co-relativos, e não podem aparecer senão juntos. Com a crescente expansão dos limites da latinitas, entendida, aqui, como a correta expressão em língua latina segundo cânones clássicos então em franca multiplicação, a elocutio foi também progressivamente assumindo o papel central. A partir desse momento, aqueles dialéticos escolásticos, até então legitimados como autoridades máximas, passaram a ser acusados de escrever mal. O nome pelo qual os humanistas os chamavam era barbari. Petrarca, por exemplo, atacou Scot e seus discípulos dialéticos com a denominação de "barbari Britanni" (Familiares I.7), enquanto que Coluccio Salutati criticava a dialética quando esta se tornava "bárbara" quanto à linguagem (De laboribus Herculis, I). Da mesma forma, Leonardo Bruni compara a filosofia válida de Aristóteles com a "barbárie" dos aristotélicos contemporâneos seus (Dialogi ad Petrum Paulum Histrum). Assim, nesse momento, os primeiros humanistas rompem com o latim que haviam aprendido e questionam sua pesada herança escolástica.

\footnotetext{
6 Scott 1910, 7.

A polêmica aqui se voltava para a imitação, sendo também, por si mesma, uma discussão acerca do que é retórica: deveria a imitação ser praticada a partir de um modelo único, sem levar em consideração as circunstâncias totalmente diferentes em que o discurso está sendo gerado, ou, por outro lado, deveria adaptar-se ao tema, à plateia, às circunstâncias?
} 
Com o advento da Reforma, muitos dos homens letrados da época, os quais eram frequentemente também membros da Igreja, viram-se às voltas com um problema que representou, para muitos, uma autêntica aporia. É que, por um lado, eles tinham de resolver a questão de como era possível que as Escrituras tivessem sido compostas em tão má elocução, enquanto os pagãos exprimiam-se de uma maneira tão convincente e agradável também acerca daquelas mesmas verdades morais nas quais a Patrística os havia julgado inferiores... E, por outro, eram acusados de lançar mão eles mesmos das armas da retórica sofisticada dos pagãos, quando deveriam contar apenas com a fiança da Verdade. Esta é uma questão recorrente nos debates religiosos do século xvi.

Ao mesmo tempo, havia aqueles que, possuindo apenas rudimentos de latim, suficientes apenas para recitar uma missa (quando a Reforma já implantava cultos dominicais em língua vernácula), viam nas discussões filológicas que não compreendiam apenas mais munição contra a Igreja. Foi assim que os comentários críticos que Erasmo fez à Vulgata levantaram contra ele a acusação, sempre repetida, de que ele "pôs o ovo que Lutero chocou".

Naquele momento, foram muitos os detratores da cultura clássica. Estes consideravam os textos antigos não apenas mentirosos mas também imorais, uma vez que falavam de deuses pagãos, os quais eram, afinal, "demônios". Para estes, a literatura antiga que conheciam não era portanto senão vestígio de idolatria. A estes, que insistem no rude latim cristão, negando a importância do estudo dos clássicos, Erasmo e outros humanistas chamarão de barbari.

Outros tentaram uma assimilação da literatura pagã pela cristã, a qual não foi, no entanto, quase nunca pacífica. ${ }^{8}$ Houve tentativas de reconciliação, mas algumas soluções encontradas poderiam nos parecer nada menos que ingênuas. Por exemplo: havia em circulação uma tentativa de explicar moraliter as Metamorfoses de Ovídio. Esse livro foi falsamente atribuído a um dominicano inglês do século xiv, Thomas de Walleys, mas seu verdadeiro autor era o beneditino Pierre de Borsuire, ou Petrus Berchorius. Para ele, a doutrina cristã encontrava-se dissimulada sob as fábulas alegóricas das Metamorfoses: Diana seria a Virgem Maria e Baco, Jesus Cristo. Esse

${ }^{8}$ A consciência dessa convivência de irreconciliáveis, porém, segundo Mack (1993, 3), característica dos textos do século XVI e começo do XVII. Ele menciona os sonetos de Shakespeare e Sidney, as songs de Donne, os ensaios de Montaigne e de Bacon, bem como Rabelais etc., bem como Milton, que, em seu Paradise Lost, teria escrito "the logical epic". Nós, luso-falantes, poderíamos acrescentar aqui os sonetos de Camões, para dar apenas um exemplo desse momento em que dialética, retórica, cristianismo, humanismo, e tudo o mais se somam e se fundem num todo desafiador e nem sempre harmonioso. Tudo isso vai se justapor e se contrapor por muito tempo, numa "convivência" que encontra no oxímoro a figura de linguagem que melhor a representa. 
livro teve imenso sucesso e conheceu várias edições até 1521, a ponto de ser satirizado no Gargantua de Rabelais. Erasmo se referiu a ele numa carta de 1518, chamando-o pura e simplesmente de insulsissimum...9

Alguns humanistas, por outro lado, optaram pela eliminação da herança cristã e lançaram-se à imitação dos modelos antigos como se o mundo não tivesse mudado desde a República romana. Pietro Bembo, por exemplo, afirmava que não lia a Vulgata para não corromper seu estilo... ${ }^{10}$ Em Roma, acabaria mesmo por formar-se uma sociedade de literati, cujo propósito era jamais usar qualquer palavra que não pudesse ser encontrada em Cícero, o que seus membros tinham de prometer por meio de um voto que faziam. ${ }^{11}$ Estes abandonaram completamente o léxico cristão e devotaram-se ao estilo ciceroniano. Um episódio narrado pelo próprio Erasmo, ainda que sem citar nomes, nos conta que, em 6 de abril de 1509, Tommaso Inghirami, conhecido como Fedra, pronunciou, no Vaticano e na presença do papa Júlio II, um sermão à maneira clássica:

Ele evocava os Décios ${ }^{12}$ e Quinto Cúrcio, ${ }_{13}^{13}$ que se haviam consagrado aos deuses manes pela salvação da República, assim como Cécrope, ${ }^{14}$ Meneceu, ${ }_{15}^{15}$ Ifigênia ${ }^{16}$ e tantos outros, para os quais a salvação e a dignidade da pátria haviam sido mais caras do que a própria vida. Em contrapartida, deplorava muito lugubremente o fato de que privilégios haviam sido concedidos por decretos públicos aos homens valentes que haviam corrido perigos para vir em socorro da República (para uns, uma estátua de ouro colocada no fórum, para outros, honrarias divinas por decreto), mas Cristo, por suas boas ações, recebeu do povo ingrato dos judeus a cruz no lugar do prêmio, depois de ter sofrido duros castigos e padecido a suprema ignomínia. E assim nos apresentava como digno de compaixão aquele homem bom e inocente e que merecia o melhor de seu povo, como

${ }^{9}$ Allen 1906, 388.

${ }_{10}$ Apud Léonas, Alexis. Recherche sur la langage de la Septante. Fribourg: Academic Press, 2005.

${ }_{11}$ Scott 1910, 22.

12 Três foram os Décios: avô, pai e filho. Os três se sacrificaram pela pátria, em episódios conhecidos como deuotiones. A mais famosa foi a de Públio Décio, que levou Roma à vitória na batalha pela prática de um ritual, no qual ele se ofereceu aos deuses da morte e partiu para a batalha com roupas sacrificiais.

${ }^{13} \mathrm{Na}$ verdade, Marco Cúrcio, que, em 362 a. C., atirou-se armado e sobre seu cavalo num abismo que se abriu no fórum romano e que só se fecharia, segundo o oráculo, quando fosse preenchido com a coisa mais valiosa que havia em Roma.

${ }^{14}$ Lendário fundador e rei de Atenas, o primeiro que afirmou ter sido escolhido por Zeus. Ordenou que sacrifícos fossem feitos a ele, como divindade suprema. Mas aqui parece tratar-se de um engano de Erasmo, que teria querido dizer Codro, rei de Atenas que sacrificou a própria vida para garantir a vitória sobre os espartanos.

${ }_{15}$ Filho de Creonte, sacrificou a própria vida por Tebas.

${ }_{16}$ Filha de Agamêmnon, sacrificada à deusa Ártemis para que os deuses permitissem que o exército grego zarpasse contra Tróia. 
se deplorasse a morte de Sócrates ${ }^{17}$ ou de Focião, ${ }^{18}$ quando estes, sem terem cometido crime nenhum, foram obrigados a beber cicuta, pela ingratidão de seus cidadãos; ou a de Epaminondas, ${ }^{19}$ que, por seus famosos feitos, viu-se compelido a defender-se em um processo capital perante seus concidadãos; ou a de Cipião, ${ }^{20}$ que, depois de tantos bons serviços para a República, partiu para o exílio; ou a de Aristides, ${ }^{21}$ a quem o povo ateniense, não suportando a inveja de seu apelido (uma vez que por sua conhecida integridade moral era chamado pelo vulgo "o justo"), ordenou-lhe partir para o exílio em ostracismo. ${ }^{22}$ Eu pergunto: o que se poderia dizer de mais frio ou mais inepto? 870. E, no entanto, emulou Cícero, na medida de suas forças.

De resto, nenhuma menção sobre o plano oculto do Deus supremo, que quis redimir o gênero humano da tirania do diabo desta forma inaudita, por meio da morte de seu único filho; tampouco sobre os mistérios: que é morrer com Cristo, que é ser sepultado com ele, que é ressuscitar com ele. Deplorava a inocência de Cristo, denunciava a ingratidão dos judeus; mas não deplorava nossa malícia, nossa ingratidão, nós, que, assim redimidos, enriquecidos por tantos benefícios, convocados com inaudita benignidade a tão grande felicidade, nós, em troca e no que dependia de nós, nós o crucificamos e nos voltamos para o outro lado, para a tirania de Satanás, escravos da avareza, do luxo, das volúpias, da ambição, entregues a este mundo mais do que jamais o foram os pagãos, aos quais Deus ainda não havia revelado esta celeste filosofia.

Já, por outro lado, quando tratava, com grande esforço, de nos conduzir à alegria, mais vontade eu tinha de chorar, ao ouvi-lo comparar os triunfos ${ }^{23}$ de Cipião, ${ }^{24}$ de Paulo Emílio $^{25}$ e de Caio César ${ }^{26}$ e os imperadores incluídos no número dos deuses ${ }^{27} \mathrm{com}_{\mathrm{o}}$ triunfo da cruz. Quem quisesse realçar com palavras a glória da cruz deveria haver tomado como modelo o apóstolo Paulo, mais do que Cícero. 875. Quanto Paulo se exalta nesse tema, quanto cresce, se ensoberbece, reina e triunfa, como que olhando de cima todas as coisas mundanas, toda vez que começa a pregação da cruz! Que dizer ainda? Aquele romano falou de forma tão romana que eu não ouvi nada sobre

${ }^{17}$ Sócrates (469-393 a.C.), filósofo ateniense imortalizado por Platão. Obrigado a beber cicuta em 393 a.C.

${ }_{18}$ Político e general ateniense, Focião (402-318 a.C.) foi condenado injustamente a ingerir veneno. Foi reabilitado postumamente.

${ }_{19}$ Epaminondas (IV a.C.), general tebano que reteve seu exército além da campanha pela libertação de Tebas do domínio espartano, o que configurava crime capital. Foi destituído, mas reabilitado posteriormente.

${ }^{20}$ Conhecido como Cipião Africano, Públio Cornélio (235-183 a.C.) venceu Aníbal e livrou Roma da ameaça cartaginense. Acusado de ter sido subornado por Antíoco, morreu no exílio.

${ }^{21}$ Aristides, nome importante no estabelecimento da supremacia ateniense no quinto século a.C. Condenado ao ostracismo em 482 a.C.

${ }^{22}$ Procedimento ateniense pelo qual um líder político poderia ser enviado para o exílio por dez anos. Em Plutarco (Aristides 7), conta-se o famoso episódio em que um ateniense analfabeto queria votar pelo ostracismo de Aristides porque já não suportava ouvir que ele era "o Justo"...

${ }^{23}$ Desfile pelas ruas de Roma de um general vitorioso e seu exército.

${ }^{24}$ Triunfo após a queda de Aníbal.

${ }^{25}$ Após derrotar o rei Perseu da Macedônia, em 168 a.C., teve um triunfo que durou três dias.

${ }^{26}$ Em 46 a.C., desfilou no triunfo mais duradouro e mais luxuoso até então.

27 A apoteose. 
a morte de Cristo. E, no entanto, parecia aos ciceronianos que aquele ambiciosíssimo candidato à eloquência ciceroniana havia falado maravilhosamente, quando não tinha dito nada sobre o assunto em questão, do qual parecia nem entender nem gostar; e tampouco dizia nada adequado, nem havia movido as paixões. Tão só apresentava o mérito de haver pronunciado à maneira romana e de haver reproduzido algo de Cícero. Poder-se-ia aprová-lo como exemplo de sua inclinação natural e de seu talento, se tal discurso tivesse sido feito por um menino perante outros meninos na escola. 880. Mas, em um tal dia, perante tal auditório, relativo a tal tema, que estava fazendo, por favor? ${ }^{28}$

Estes, os ciceronianos, atacavam Erasmo porque ele escrevia em latim sobre qualquer tema e não temia empregar palavras não ciceronianas ou argumentos de autoridade extraídos da Bíblia ou da Patrística. Aqueles, que consideravam a Antiguidade perniciosa, atacavam Erasmo por ser editor e defensor dos clássicos e por haver ousado questionar, como tradutor, termos usados por Jerônimo na Vulgata.

\section{ERASMO CONTRA OS BÁRBAROS}

Se uns e outros atacaram Erasmo, este, por sua vez, investiu também contra uns e outros. Sem jamais concordar com radicalismos de nenhuma espécie, também na eloquência Erasmo procurará a conciliação entre a vida cristã e a literatura pagã. Assim, começa sua carreira com um Antibarbarorum liber, no qual defende os studia humanitatis, pois "o que escrevemos e falamos em latim por toda parte, nós o recebemos dos pagãos; os alfabetos foram criados por eles, o uso do discurso foi inventado por eles também" ("quod scribimus, quod utcunque Latine loquimur ab ethnicis accepimus; ab illis reperti characteres, ab iisdem orationis usus inuentus", 80.496).

O Antibarbari é sobretudo um discurso com que um então iniciante Erasmo ataca os inimigos das letras, como se estas fossem perniciosas para o jovem cristão. Essa acusação não fazia sentido, responde, especialmente porque os jovens eram obrigados a estudar anos a fio o pagão Aristóteles... Dentre os autores da Patrística, chama em seu auxílio especialmente Jerônimo e Agostinho. Do primeiro, cita a metáfora com que, em mais de uma ocasião, Jerônimo defende as letras pagãs: assim como o judeu estava autorizado pelo Deuteronômio a desposar uma escrava, contanto que ela tivesse a cabeça e as sobrancelhas raspadas, assim também ele poderia tornar a "sabedoria secular" a "matrona de Israel", depois de raspar e cortar

${ }^{28}$ Erasmo de Roterdã, Diálogo Ciceroniano. Trad. Elaine C. Sartorelli. São Paulo, Ed. Unesp, 2013, pp. 91-4. 
tudo o que nela estivesse morto, ou seja, "a idolatria, o prazer, o erro, a luxúria". ${ }^{29}$ A explicação é que o cristão pode "desposar" a eloquência antiga, com a condição de que a "purifique", privando-a daquilo que não tem outra utilidade senão a ornamentação. Do segundo, recorre especialmente ao De Doctrina christiana, para enumerar as disciplinas pagãs que são lícitas e úteis, entre as quais dá proeminência à dialética, sem falar em retórica - o que, segundo Chomarat, ${ }^{30}$ revela "o embaraço" de Erasmo, o qual é também, contudo, de Agostinho, uma vez que este prescrevia que o orador cristão falasse com sabedoria mais do que com eloquência: "interest magis ut sapienter dicat christianus orator, quam ut eloquenter". ${ }^{31}$ Mas isso não impede que Agostinho aproveite aqui uma imagem bíblica, segundo a qual os judeus, em sua saída do Egito, haviam sido autorizados por Jeová a carregar com eles objetos valiosos (joias de prata e ouro e vestes ${ }^{32}$ ), os quais, segundo ele, representariam as disciplinas liberais a serviço da verdade... Erasmo aproveita esse comentário e fala de "sapientiae aurum, eloquentiae argentum, bonarum litterarum supellex" ${ }^{\prime 33}$ e concede a primazia dentre as instituições humanas às leges loquendi. ${ }^{34}$

Quanto ao argumento de que o cristão não deveria perder tempo com autores que estavam no inferno, Erasmo responde que não nos compete discutir se aqueles cujos escritos nos chegaram haviam sido condenados, "como se muitos cristãos não estivessem ardendo ali!" ("quasi non et multi Christiani illic ardeant")..$^{35}$

Futuramente, Erasmo chegará a admitir que a língua dos evangelistas é "grosseira, incorreta, irregular, por vezes com francos solecismos" ("sermo non solum impolitus et inconditus, verum etiam imperfectus, perturbatus, aliquoties plane soloecissans ${ }^{\prime 36}$ ), mas isso para ele não parecia constituir um problema, uma vez que buscava demonstrar que o conhecimento das línguas pelos apóstolos nada tinha de miraculoso ou de intervenção do Espírito Santo, mas era simplesmente uma aquisição humana; a língua que o próprio Cristo falava, dizia, era "vulgatissimo maximeque populari". Mais ainda, tenta mostrar que a rudeza da língua apostólica não prejudica a men-

${ }^{29}$ Argumento que Jerônimo já havia utilizado em carta ao Papa Damaso, e retoma na famosa carta a Magnus, um orador romano (v. LXX da coleção Budé).

${ }^{30}$ Chomarat 1981, 424.

31 De Doctrina Christiana 4.5.

32 Éxodo 3.22 e 12.35.

${ }^{33}$ Antibarbarorum liber 117, 1118.

${ }^{34}$ Idem, 117, 1121.

${ }^{35}$ Idem, 80, 498

${ }^{36}$ Apud Winer, G.B. A Treatise on the grammar of the New Testament, traduzido por Moulton. Edimburgo, 1882, p. 13. 
sagem evangélica, mas, ao contrário, a favorece. É exatamente por ter sido pregada numa língua simples e sem arte ("simplici inconditoque") que o discurso dos apóstolos foi convincente. Erasmo demonstra aqui um autêntico e verdadeiro conhecimento de retórica, na medida em que aconselhava o decorum e o apte dictum, ainda que não tão "bem" dito assim.

Ao perpassar a obra de Erasmo, $\mathrm{Chomarat}^{37}$ propõe uma divisão dos argumentos do humanista holandês a favor dos clássicos em quatro pontos principais. O primeiro argumento é que os poemas antigos podem ser inofensivos e mesmo capazes de nutrir a alma dos jovens. Para ilustrar isso, ele escolhe nada menos que a segunda Bucólica de Virgílio. Dela Erasmo extrai uma defesa da amicitia entre iguais, pois nada mais infeliz (infoelicius) que a amizade desproporcional. Córidon e Alexis são diferentes em tudo... Analisando assim, "nada de vergonhoso ocorrerá ao pensamento dos ouvintes, a menos que alguém já esteja corrompido" ("nihil turpe ueniet in mentem auditoribus, nisi si quis iam corruptus accesserit"). ${ }^{38}$ Assim também, será indiferente usar amicitia ou amor, uma vez que a "aparência carnal" do poema não será abordada...

O segundo argumento é que é possível retirar das obras antigas uma lição moral ou mesmo religiosa. Isso porque os autores clássicos têm um papel formador. Suas fábulas são ímpias, mas, diz Erasmo, deveriam ser mais caras para nós do que para eles. Luciano de Samósata, por exemplo (de quem Erasmo e seu grande amigo Thomas More gostavam especialmente), não oferece qualquer risco à criança cristã, pois zomba ele próprio dos deuses, sendo portanto uma arma contra crenças supersticiosas. Quanto a Terêncio (outro autor de sua predileção), Erasmo, em carta cuja datação aponta para $1489{ }^{39}$ afirma que não vê nele nada de vergonhoso, mas exatamente o oposto: esse autor romano não visava senão a condenar os vícios morais. Erasmo entende então a comédia como moralizante, mas moralizante pelo prazer; nela, as delícias da língua desempenham um papel pedagógico. E Chomarat ${ }^{40}$ afirma que, por mais estranho que possa parecer, foi Terêncio uma das principais influências na formação religiosa de Erasmo: "assimilar Terêncio é já impregnar-se de espírito cristão. É verdade que não se trata do cristianismo da Sorbonne ou dos monges, fundado sobre a excomunhão, o anátema, a venda de indulgências e a fogueira, mas de um cristianismo propriamente erasmiano ou, antes, evangélico".

${ }^{37}$ Chomarat 1981, 425 ss.

${ }^{38}$ De ratione studii 142, 243.

${ }^{39}$ Allen 1906, 124.

${ }^{40}$ Chomarat 1981, 431. 
O terceiro ponto afirma que é preciso considerar a humanidade antes e depois da encarnação de Cristo. Se somente o exemplo e o ensinamento de Cristo permitem encontrar a plenitude da natureza humana, então obviamente é inútil buscá-la antes da encarnação, tal como os cristãos a conhecem. Mas uma espécie de graça existia antes, ainda que parcialmente, e é possível vê-la nos sábios pagãos. Em sua polêmica com Lutero sobre o livre-arbítrio, Erasmo se nega a considerar a natureza humana como radicalmente corrompida, defendendo a permanência da graça no homem, e, cristão convicto, não quis condenar ao inferno os autores antigos a quem devia tanto. Para Chomarat, seria pouco dizer que Erasmo não opõe cristianismo e poesia pagã: "ele faz mais do que conciliá-los; ele os amalgama". ${ }^{11}$

Segundo o quarto argumento, a mitologia também pode servir para expressar nada menos que verdades cristãs. No Antibarbari, Erasmo havia convidado todos os cristãos, teólogos e monges em particular, a não contar somente com a inspiração divina, mas a esforçar-se por conhecer as disciplinas humanas. Prometeu devia nos servir de modelo, uma vez que ele "utilizou todos os recursos de que a arte humana pôde se servir" ("quicquid humano artifício praestari potuit"). ${ }^{42}$ Mas o exemplo mais ilustre dos símbolos pagãos colocados a serviço do cristianismo é o dos centauros Silenos, que representam os homens em sua aparência física desprezível, mas alma sublime,;3 poder-se-ia dizer que os Silenos remetem à própria Escritura, a qual, sob uma roupagem pouco atraente, oculta uma essência grandiosa. Além disso, os Silenos, ao contrário dos monarcas e bispos e monges, não ocultam seus vícios e sua tirania por detrás de uma aparência virtuosa... ${ }^{44}$ Em suma, Erasmo não tem nenhum escrúpulo em recorrer à filosofia, à mitologia, à comédia ou ao que for para obter subsídios para aquilo que quer demonstrar, que é a possibilidade da convivência dos exemplos pagãos na vida cristã, a qual, segundo ele, não é posta à prova ou ameaçada pelo contato com o paganismo.

É preciso ainda fazer a diferença entre um paganismo altamente moral e outro, idólatra; o mesmo ocorre no cristianismo, em que a "verdadeira religião" convive com tantas superstições. E na luta contra esse cristianismo desvirtuado, que se mantém pela ignorância, o paganismo dos grandes poetas e oradores é um aliado não apenas poderoso mas também necessário.

${ }^{41}$ Chomarat 1981, p. 435.

${ }^{42}$ Antibarbarorum liber 134, 1392.

${ }^{43}$ Chomarat 1981, 436.

${ }^{44}$ Idem, ibidem. 


\section{ERASMO CONTRA OS INDOCTE DOCTI}

Além dos bárbaros, havia ainda os indocte docti, os semiletrados. Erasmo se refere a eles como aliquis imperitus, sciolus aliquis, eruditulus aliquis. São estes os falsos conhecedores que corrompem os textos e os copistas que os alteram por descuido ou ignorância.

Mas se os barbari são os iletrados e os inimigos da cultura humanística clássica, os indocte docti são também os teólogos escolásticos, que não conhecem nada senão Aristóteles. Dado um problema de fé, os indocte docti recorriam à lógica aristotélica, e não ao Evangelho, e essa apropriação da filosofia desnaturalizava e corrompia a religião, porque teses, antíteses, premissas e conclusões lógicas não respondem a questões que devem ser respondidas pela fé.

Estes, ademais, não fazem senão estudar Aristóteles, mas se voltam contra o estudo dos clássicos... Erasmo parece estar consciente do problema fundamental que subjaz nesta questão, o qual já encontramos antes e voltaremos a encontrar em seguida. $\mathrm{O}$ combate entre os humanistas e seus adversários não confronta partidários e detratores da Antiguidade, mas antes e principalmente aqueles que buscavam a "verdade" filosófica ou teológica e aqueles que se contentavam com as probabilidades da arte oratória... Em outras palavras, a inimiga a ser combatida não é a Antiguidade, mas a Retórica.

\section{ERASMO CONTRA OS CICERONIANOS}

E aqui voltamos à terceira das camadas mencionadas no início, a humanística totalmente voltada para a retórica, e especialmente Cícero. E poderíamos talvez imaginar que, como defensor dos clássicos, Erasmo fosse também um entusiasta da antiguidade a ponto de aderir totalmente a seus valores. Mas isso não aconteceu... Erasmo foi também um crítico mordaz da paganitas dos ciceronianos. Um dos pontos fundamentais de sua crítica a eles é a divinização de Cícero - divinização que, naquele contexto cristão de que Erasmo não pode ser separado, é uma acusação de paganismo. Para ele, os humanistas italianos que, em nome da admiração pelas letras antigas, rejeitam o rude e rústico estilo baixo cristão são membros de uma seita. Para estes, um discurso que fale a respeito de Deus é bárbaro e incorreto, mas outro, que mencione "Iuppiter optimus maximus" é nada menos que admirável. 
Essa discussão aparece principalmente no Diálogo Ciceroniano, de 1528, em que Erasmo zomba daqueles que não têm senão Cícero como modelo. Nesse tratado, Erasmo satiriza um "ciceroniano" (personagem inspirada no discípulo de Pietro Bembo, Christophe de Longueil), o monomaníaco Nosópono, o qual, tendo feito uma capela para Cícero, o colocou entre os santos de seu calendário. Além disso, abstém-se de carne, como os ascetas, e mantém o celibato, tudo para poder dedicar-se ao orador romano...

Pierre Mesnard, ao publicar em 1970 sua tradução francesa do Ciceronianus, classificou esse diálogo entre as obras religiosas de Erasmo, incluindo-o em um volume chamado La Philosophie Chrétienne. Para esse estudioso, Erasmo "não cessa de denunciar a mentalidade pagã que se instalou no coração da Renascença italiana e especificamente romana". ${ }^{45}$ Nós, entretanto, entendemos, com vários outros pesquisadores, que seu subtítulo, De optimo dicendi genere, nos autoriza a considerá-lo entre as obras retóricas do humanista. Embora a questão do paganismo seja de fato importante, parece-nos que a crítica de Erasmo a esse respeito também se pauta pelo princípio retórico da adequação da forma ao tema. Assim, tratar matéria cristã com estilo e léxico ciceronianos não são apenas marcas de paganismo, mas falta de decoro e prova de que o - mau - orador não compreende nem seu tema, nem seu auditório.

Cícero, diz ainda Erasmo, não pode ser modelo para um orador cristão simplesmente porque não há em sua obra as palavras "Jesus Cristo, Palavra de Deus, Espírito Santo ou Trindade, nem Evangelho, nem evangelista, nem Moisés, nem profeta, nem Pentateuco, nem salmos, nem bispo, nem arcebispo, nem diácono, nem subdiácono, nem acólito, nem exorcista, nem Igreja, nem fé, esperança e caridade, nem mesma essência das três pessoas, nem heresia, nem símbolo, ${ }^{46}$ nem sete sacramentos da Igreja, nem batismo ou batista, nem confirmação, nem eucaristia, nem sagrada unção, nem penitência, nem confissão sacramental, nem contrição, nem absolvição, nem excomunhão, nem sepultura eclesiástica, nem missa, nem outras inumeráveis palavras das quais consiste toda a vida dos cristãos". ${ }^{47} \mathrm{Ou}$ será que os cristão deveriam dizer "persuasão cristã" em lugar de "fé cristã?"

Os argumentos todos subordinam-se aqui a um somente: o retórico. Se a principal qualidade de um orador é falar apropriadamente, então nada mais importante que aquilo a que os antigos chamavam decorum. Para isso é preciso que o orador e seu discurso sejam considerados em relação às circunstâncias (público, tema, causa etc). Erasmo faz pois a defesa do apte dicere,

${ }_{45}$ Mesnard 1970, 11.

${ }_{46}$ O credo, uso estabelecido no tempo de Cipriano.

${ }^{47}$ Diálogo Ciceroniano, 2013, 98. 
contra a emulação símia dos falsos ciceronianos italianos, cujos métodos são ilustrados e satirizados por meio do trabalho de Nosópono. Para este, a res tem de mostrar-se servil perante as predeterminadas e intocáveis uerba de Cícero. Uma fala do Ciceroniano explicita o ridículo desse método: "Isso não é diferente de um excelente artífice que preparasse uma roupa magnífica e grande quantidade de jóias, de anéis e de pedras preciosas para ela, e só depois forjasse uma estátua de cera à qual acomodasse esses ornamentos, ou, mais ainda, que ele a confeccionasse para os ornamentos!" 48

Erasmo ataca ainda aqueles que aceitam algumas palavras como sublimes porque são antigas e assinadas por um romano, enquanto rejeitam outras como reles e bárbaras, porque cristãs. A razão, segundo ele, é o paganismo:" "Somos cristãos só de nome; nosso corpo foi banhado com água benta, mas nossa mente não está lavada; nossa fronte foi marcada com o sinal da cruz, mas nosso espírito execra a cruz; confessamos a Jesus com a boca, mas é Júpiter Ótimo Máximo e Rômulo que levamos no peito". ${ }^{00}$

Para este humanista e defensor dos clássicos, ao discurso do cristão "se lhe agrega muito decoro, cada vez que virmos intercalada uma sentença tirada do mais recôndito santuário das sagradas escrituras ou do depósito de incensos ou perfumes do Espírito Santo. Uma somente, no lugar certo, trazida da alma, e veremos como se acrescenta muito mais dignidade ao nosso discurso do que se lhe fossem acrescentadas dez mil frases tiradas dos escritos de Ênio ou Ácio, que são consideradas por eles as mais elegantes". ${ }^{51}$

\section{DE COPIA}

As discussões de Erasmo acerca daqueles que seriam barbari, indocti docte ou ciceroniani giram, afinal, em torno dos modos de recepção, leitura e imitação dos autores clássicos em uma realidade diferente daquela em que os clássicos foram produzidos, tal como o era o século xvi em relação à Antiguidade. Como empregar os modelos herdados da Antiguidade com pertinência? Uma importante obra nesse sentido é seu De Utraque Verborum ac Rerum Copia, de 1512, o mais reeditado livro da Renascença (169 edições no

${ }^{48}$ Diálogo Ciceroniano, 2013, 26.

${ }^{49}$ Em latim, paganitas, que parece envolver não apenas questões religiosas, também culturais e especialmente linguísticas.

${ }_{50}$ Diálogo Ciceroniano, 2013, 110.

${ }^{51}$ Idem, 111. 
século XVI, 6o das quais de 1512 a $1530^{52}$ ), que "combinou um entendimento dos tropos e das figuras com o conhecimento de uma vasta gama de autores e uma aguda adaptação de técnicas dialéticas, definindo e estabelecendo a centralidade da amplificação pelos próximos oitenta anos". ${ }^{53} \mathrm{E}$, embora esta não tenha sido a preocupação de Erasmo, não espanta perceber que, dentre todas as suas obras, aquela preocupada com a elocução (a que seus contemporâneos chamavam ornamentação) tenha sido a mais influente. Isso porque uma das características do Renascimento no campo da retórica foi precisamente a aproximação do conceito de elocutio com o emprego dos ornati.

O livro De Copia se autoproclama um método para enriquecimento de todos os tipos de discurso. Nele, Erasmo ensina como fazer variações sobre um tema dado, combinando um estudo de tropos e figuras de linguagem extraídos de um vastíssimo leque de autores com uma adaptação das técnicas da dialética. Em suma, trata-se de como dizer a mesma coisa de formas diferentes, segundo a conveniência. Erasmo o considerava um manual escolar ("haec scholastica sunt", diz, em carta a Batt ${ }^{54}$ ), um commentarius, "opus utilisssimum", ao qual, no entanto, faltava "um justo cuidado" ("et fateor et doleo huic operi iustam curam defuisse" ${ }^{\prime 55}$ ). A obra é, contudo, nova, uma vez que a existência de um manual inteiramente voltado para a aquisição de copia não foi uma herança clássica, mas uma inovação humanística.

Erasmo não considerava a copia apenas como riqueza de uerba (a ubertas orationis), mas também abundância de res. Dessa forma, ele, como Quintiliano, divide copia em duas partes: de palavras e de coisas. Assim, a primeira edição de seu livro (1512) recebeu o título de De duplici copia verborum ac rerum e as demais, De utraque verborum ac rerum copia. ${ }^{56}$ Desse modo, a copia não reside apenas em falar de modo elegante, porém em ser capaz de transitar por todos os estilos, altos, médios ou baixos, o que aproxima Erasmo mais da retórica clássica que dos trabalhos quinhentistas que até então haviam defendido a identificação entre a retórica e a ornamentação da linguagem, geralmente associada aos estilos elevados. Não basta, segundo Erasmo, empregar as figuras de linguagem nos discursos como ornamentação, decorativa mas não significativamente. Antes dever-se-ia entender esta parte da retórica como integrante de um todo, formado por uirtutes elocutiones.

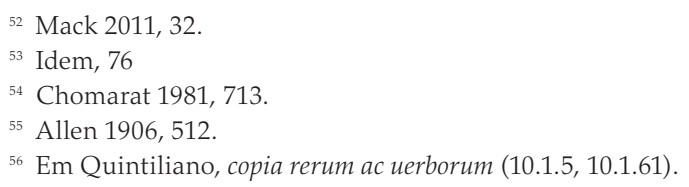


Erasmo segue mais a Quintiliano do que a Cícero, o qual parece entender a palavra copia como algo mais próprio da eloquência sublime e do gênero alto, tal como podemos ver no Orator 97: amplus, copiosus, grauis, ornatus; no Orator 20: uehementes, uarii, copiosi, graues; e no Orator 29: ornate et grauiter et copiose dicere, por exemplo. Em Erasmo, a copia designa a abundância dos recursos de que pode dispor o orador, a faculdade de poder escolher num depósito ricamente provido. Isso significa que o orador pode, a sua escolha, usar um estilo copioso, no sentido ciceroniano, ou adotar um estilo sóbrio. Quem será mais apto a exprimir uma idéia com o menos de palavras possível senão aquele que sabe enriquecer o tema? A seu gosto, e segundo seu interesse, o orador pode ser generoso (largus) ou pródigo (prodigus), ou, por outro lado, avaro (tenax) ou econômico (parcus). Um e outro com virtude, um e outro com vício.

\section{A COPIA VERBORUM}

Na copia das palavras, de nosso interesse neste artigo, ele discorre sobre os métodos por meio dos quais é possível encontrar formas diferentes de se dizer a mesma coisa. Muitos deles consistem simplesmente em variar uma palavra da sentença.

A uariatio é necessária para não aborrecer os ouvintes ou leitores, uma vez que ninguém é capaz de suportar um discurso sempre igual. E também porque a própria diversidade dos objetos exige variedade do dizer. Pensando retoricamente, em termos de accomodatio, decorum, apte dicere etc, Erasmo afirma no decorrer de toda a sua obra que o conceito abstrato e "universal", permanente e ontológico, não é capaz de dar conta do fato de que o real é sempre singular, particular, individualizado. Se a vida é transitória e sempre nova, um discurso monocórdio, sempre igual e indiferente à reação que desperta, seria como a própria morte.

Resumindo a questão ao mínimo, o método de Erasmo consiste da tentativa de, tendo escolhido uma frase, dar-lhe o maior número possível de variáveis. Nem todas as palavras ou figuras são boas ou apropriadas para todos os discursos, mas cada discurso deve ser apropriado, correto, elegante, puro ("ut apta, ut Latina, ut elegans, ut pura sit oratio" ${ }^{57}$ ). Aquele que visa à concisão (breuieloquentia) deverá ser capaz de escolher, eliminar, não reter senão o indispensável. É preciso evitar a obscuridade, mas sem omitir 
o essencial; copia é, pois, ordem e equilíbrio. Para atingi-la, ressalta que os alunos deveriam praticar a imitação dos modelos clássicos e, de tanto lê-los, aprendê-los de cor e ter a eles acesso automático. Não há nenhum outro critério senão a correção. $\mathrm{O}$ cabimento e a adequação têm precedência mesmo sobre a abundância. Uma das críticas que Erasmo endereça ao tradutor do Antigo Testamento é a de copiae affectatio, que o força a traduzir a mesma palavra grega, repetida no original, por palavras latinas diferentes. ${ }^{58}$

E este é um traço fundamental de Erasmo, em qualquer aspecto, por qualquer ângulo, de sua obra: o conhecimento técnico é necessário, mas não é dele que se trata. Conhecer a gramática é importantíssimo, mas, mais do que reverenciá-la, é preciso praticar a língua viva: "latine, non grammatice loqui".

Isso quer dizer que a concisão e a abundância não são qualidades absolutas, mas relativas ao tema, às circunstâncias, à intenção. O orador verdadeiro mostrará ter uma ou outra segundo a ocasião. Pergunta-se então se Erasmo se filia a alguma das escolas de eloquência reconhecidas. Pelo De copia, qualquer possibilidade fica em aberto. O mesmo se considerarmos os três gêneros de estilo (sublime, baixo e médio). Erasmo preceitua que se escolha ora este, ora aquele, segundo as circunstâncias. O único erro capital é a falta de harmonia entre o tipo de eloquência e o estilo e entre o discurso e o contexto.

\section{A HERANÇA DE ERASMO}

Os "usos especiais da linguagem que impressionam uma plateia foram considerados como parte central da educação retórica desde o helenismo".59 Na retórica clássica, porém, o ornatus possuía um lugar que, se lhe garantia importância, dava-lhe, por outro lado, uma moldura limitadora: era uma das virtutes elocutionis da terceira parte da retórica. Ou seja, era uma das muitas partes que formavam o todo. E nem era uma parte muito grande... O tratamento mais extenso que recebe está no quarto livro da Rhetorica Ad Herennium, em que sessenta e quatro figuras de linguagem são descritas e explicadas.

A identificação entre retórica e elocução ou entre elocução e ornamentos era desconhecida dos autores clássicos. As origens desse modo de entender a retórica tem suas raízes na divisão das áreas de estudo promovida pelo trivium e quadrivium medievais. Nesse sistema, cada área estuda as questões

\footnotetext{
${ }_{58}$ Nas Adnotationes ad Nouum Testamentum (in Chomarat 1981, 759).

${ }^{59}$ Mack 2011, 208.
} 
que lhe concernem, e, nessa época de predomínio da lógica e da dialética, coube à retórica a elocução, entendida como sinônimo de estilo ornado. Quando os escritos de Cícero são redescobertos, trazendo, com isso, um novo modo de se entender o próprio discurso, e fazendo vir à luz um acúmulo de conhecimento que não havia circulado por tantos séculos, tenho sobrevivido apenas por citações, referências e fragmentos, essa redescoberta produziu também diversos tipos de questionamentos e teorias em torno da linguagem e do discurso. Alguns receberam essas descobertas textuais na mesma chave em que já eram conhecidas anteriormente, ou seja, é possível perceber que certos humanistas entenderam a retórica clássica como a retórica era entendida em tempos pré-humanísticos: como sinônimo de ornamento.

Já em Petrarca "a erudição da língua é própria do orador", ${ }^{60}$ ao passo que, para Trebizonda, "dentre todas as outras partes da virtude da retórica, a elocução me parece aquela que com mais diligência deve ser praticada. Não apenas porque foi negligenciada por completo pelos escritores de habilidade, mas também porque, dentre as outras, parece ser a mais proveitosa". ${ }^{61}$

Quanto a Erasmo, este havia proposto, com seu De Copia, uma maneira ao mesmo tempo "nova" e antiga de pensar a eloquência. Ele próprio insiste em sua originalidade e chega mesmo a dizer: "eu fui o primeiro a vislumbrar o assunto e a dar conta dele". ${ }^{62}$

E, ao mesmo tempo, Erasmo acaba por fazer o caminho inverso dos manuais de retórica antigos, que iniciam com a inuentio para chegar à elocutio. Ele, ao contrário, trata primeiro da copia das palavras, e em seguida da copia dos temas. É preciso aplicar aquilo que foi aprendido, e não apenas para delectare.

O acesso à copia erasmiana vem pelo "estilo" [elocutio], um dos cinco "ofícios" da retórica clássica [partes artis], uma jornada que culmina em outro desses ofícios, o pensamento retórico ou "invenção" [inuentio]. Por essa razão, a segunda parte do De Copia sai da obsessão para com as palavras e mergulha na mais multifacetada característica da retórica clássica. ${ }^{63}$

Assim, embora não fosse contrário ao uso decorativo das figuras, Erasmo não deixou de perceber o poder persuasivo que estas contêm. Tome-se como exemplo a epístola introdutória de sua importante obra Parabolx:

\footnotetext{
${ }_{60}$ "Animi cura philosophum quærit; eruditio linguæ oratoris est propria. De Rebus Familiaribus et Varix."

${ }_{61}$ "Caeteris omnibus Rhetoricæ facultatis partibus, elocutio mihi diligentius tractanda uidetur, non solum quoniam omnino ab artis scriptoribus neglecta est, uerum quoniam inter alias utilissima uideatur. Retoricorum Libri V."

${ }^{62}$ In Erasmus: letters 142 to 297, 1501 to 1514. Toronto and Buffalo: Toronto University Press, p. 227.

${ }_{63}$ Sloane 1991, 114
} 
Cada um dos demais ornamentos da linguagem traz para o discurso certa e particular graça e aptidão: sozinha, a metáfora mostra uma totalidade de forma mais completa do que todas as outras exornações. Queres deleitar? Nada tem mais encanto. Esforças-te para ensinar? Nenhuma outra serve para demonstrar de forma mais eficaz e clara. Planejas uma forma de dobrar alguém? Nada acrescenta mais agudeza. Dedicas-te à copia? Em nenhum outro lugar há acervo mais rico. [...] Buscas o sublime? Essa [figura] eleva o que quer que seja o quanto for. [...] Buscas a enargeia e a iluminação? Nenhuma é melhor para nos pôr as coisas diante dos olhos. ${ }^{64}$

No entanto, ao mesmo tempo em que valoriza a importância das figuras de linguagem, não deixa de apontar também como um discurso belamente ornamentado, porém destituído de boas ideias, é ineficaz. O mesmo pode ser percebido já no início do De Copia: o discurso, para possuir uma eficácia máxima, deve ser resultado de uma união correta entre ideias e palavras. Essa essencial conformidade entre res e uerba reflete a antiga dinâmica da escrita clássica, que buscava a harmonia entre as partes artis.

Erasmo nunca escreveu um manual de retórica que a cobrisse como um todo e que introduziria (ou, talvez, substituiria) os manuais clássicos, nem mesmo se concentrou com a mais duradoura das características da nova apresentação da retórica: a lista de tropos e figuras de linguagem. Estas duas tarefas foram tomadas pela próxima geração, conduzida por Phillip Melanchton. ${ }^{65}$

No que tange aos manuais estritamente dedicados às figuras de linguagem, os quais, em número crescente, confirmam a tendência renascentista de conceder à elocução o papel central, poder-se-ia apontar sua origem no livro Rudimenta Grammatices, de Perotti (escrito em 1468 e publicado em 1473). A seção De Figuris dessa obra é bastante curta, mas circulou muito na segunda metade do século $\mathrm{xv}$, uma vez que a obra foi impressa um total de 133 vezes, sendo 115 delas antes de $1500 .{ }^{66}$ Há ainda dois tratados que o seguiram e que versam apenas sobre as figuras de linguagem e que são escritos em verso. O primeiro, Carmen de Figuris, de Antonio Mancinelli, de 1489, descreve noventa e oito figuras em duzentos e sessenta e oito versos; o segundo, De Figuris, de Ioannis Despauterius (Jean Despautère), de

\footnotetext{
${ }_{64}$ "Cæterorum ornamentorum singula suam quandam ac peculiarem adferunt gratiam et commoditatem dictioni: metaphora sola cumulatius præstat vniuersa, quam exornationes reliquæ singula. Delectare vis? nulla plus habet festiuitatis. Docere studes? non alia probat velefficaci [vel efficatius (Mack 2011, 89)], vel apertius. Flectere paras? nulla plus addit acrimoniæ. Studes copiæ? nusquam supellex locupletior. [...] Sublimitatem affectas? hec [haec (Mack 2011, 89)] quiduis

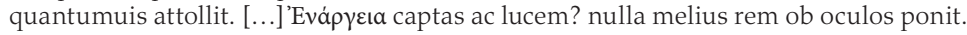

${ }_{65}$ Mack 2011, 103.

${ }^{66}$ Idem, 211-12.
} 
1512, descreve, em cem versos, noventa e duas figuras. ${ }^{67}$ Este é publicado no mesmo ano da primeira edição do De Copia.

Outros exemplos: em 1516, um correspondente de Erasmo, Petrus Mosellanus (Peter Schade) publica um dos mais importantes manuais de figuras de linguagem do século xvi, o Tabulæ de Schematibus et Tropis, que contou com oitenta e seis edições até $1590 .{ }^{68} \mathrm{~A}$ introdução dessa obra tornou-se influente por "enfatizar a importância das figuras para chamar a atenção de um auditório e para deleitá-lo", ${ }^{69}$ além de comentar formas de memorizar todas as figuras. Melanchthon, por sua vez, foi importante pela profusão de suas Institutiones Rhetoricæ (1521) e dos Elementa Rhetorices (1529), publicados ao todo cento e uma vezes até $1610 .{ }^{70}$ Neste último, um pequeno livro de sessenta páginas, o autor luterano faz um catálogo de figuras, estudadas na parte dedicada à elocutio. Para ele, "a elocução é o ornato e esplendor do discurso" e "a elocução amplifica e enriquece e orna". ${ }^{71}$

Não por acaso, o De Copia, cuja primeira parte era inteiramente voltada para a elocução, foi o livro de Erasmo que alcançou maior sucesso naquele momento.

O culto da eloquência crescia em importância desde a época de Petrarca e Boccaccio, atingindo seu ápice de aceitação pública na época de Erasmo. Qual livro poderia esperar mais aprovação imediata de um público leitor apaixonado pela eloquência do que um que os dirigia exatamente para a copiosidade e elegância de estilo que estava no centro da retórica do Renascimento e, mais ainda, um livro vindo das mãos daquele que já era vastamente aclamado como o "novo príncipe da eloquência"? 72

Porém, dada a nova mentalidade que se impunha, mesmo o De Copia de Erasmo, com vendas e circulação extraordinárias para a época, foi utilizado apenas parcialmente, e precisamente na sua primeira parte, a copia verborum. Existem evidências ${ }^{73}$ de que apenas as páginas da primeira metade do livro de Erasmo mostravam desgaste por seu uso na Inglaterra do século XVI, seja pelos alunos iniciantes, seja pelos avançados, de modo que parece que os professores ingleses avançavam com seus alunos apenas nessa parte do livro. Em algumas edições da obra, inclusive, foram incluídas as figuras de linguagem, fazendo-a ser lida como qualquer outro manual da época.

${ }^{67}$ Idem, 212-13.

${ }^{68}$ Idem, 214.

${ }^{69}$ Idem, ibidem.

${ }^{70}$ Idem, 216.

71 "Elocutio est orationis ornatus et splendor e elocutio amplificat et auget et ornat."

72 Sowards 1958, 125-26.

${ }^{73}$ Ver Sloane 1991, 114, explicando as teorias descritas por T. W. Baldwin em seu William Shakespeare's Small Latine and Lesse Greeke. 
Os comentários feitos ao De Copia o tratavam como mais um texto sobre a eloquência. O mais completo de todos, talvez, mas que deixava de lado, porém, as figuras de linguagem. O comentário de Weltkirchius, por exemplo, que era frequentemente reeditado com o De Copia, "adiciona definições das figuras de linguagem que Erasmo não haveria de outro modo incluído, com a consequência de que muitos pupilos poderiam ter acesso a uma bastante extensa lista de figuras e tropos dentro de seu manual sobre a copia".74

Assim, a retórica, que havia voltado a ganhar um lugar de destaque nos estudos, continua, porém, a ser entendida majoritariamente como sinônimo de oratória e elocução. Essa tendência vai se tornando progressivamente mais importante no decorrer do século XVI, atingindo seu ápice em Ramus e Talon.

O recrudescimento das guerras religiosas também parece ter causado nova subdivisão nos discursos. Aqueles mais diretamente envolvidos nas polêmicas religiosas ganharam o acréscimo de um forte elemento patético, naquele momento em que a retórica voltou a ser instrumento poderoso de busca de adesão, ainda que utilizada para um tema - a conversão religiosa - para o qual os antigos jamais poderiam ter imaginado. A partir de então, impôs-se progressivamente também a noção de que a elocutio, com suas figuras de linguagem, não serve apenas à função delectare. Houve portanto uma mudança de ênfase nos estudos retóricos que, principalmente influenciada por Melanchthon, um dos primeiros e principais nomes da Reforma, causou um "aumento na ênfase do papel das paixões na persuasão que levou, entre 1540 e 1640, a um importante reajuste na ênfase da retórica. Das três metas retóricas, mouere, docere e delectare, o mouere tornou-se a mais desejada; das cinco partes do processo composicional, a elocutio recebeu a maior atenção. As duas mudanças estavam interligadas, uma vez que os recursos da língua eram desenvolvidos pela elocutio a serviço de fins persuasivos" ${ }^{75}$ Além disso, e por outro lado, percebe-se que, com o estudo das figuras de linguagem, os textos bíblicos poderiam ser mais valorizados do ponto de vista literário. E, sendo assim, esse tipo de estudo proliferou-se cada vez mais.

Quanto aos textos literários, não polêmicos, estes aproximaram a retórica do ornamento cada vez mais. De Tropis Orationis et Dictonis, de 1521, de Johannes Reush, bem como o Epitome Troporum ac Schematum, de 1540, de Susenbrotus, além de manuais vernáculos seguindo essa tendência, como os ingleses A Treatise of Schemes and Tropes (1550) e Treatise of the Figures of Grammer and Rhetorike (1555), ambos de Richard Sherry bem como as duas edições 
do The Garden of Eloquence (1577; 1593), de Henry Peacham, o mais completo manual de oratória da época, o qual apresenta um total de 227 figuras de linguagem, com explicações, exemplos e, no caso das figuras da segunda edição, seções com os cuidados e usos de cada um dos ornamentos.

Ou seja, os herdeiros de Erasmo acabam por utilizar seu discurso como legitimador de uma tendência que já é percebida em humanistas anteriores ao neerlandês, mas que vai ganhando maiores dimensões após a publicação do De Copia. Peacham, por exemplo, já no fim do xvI, escrevendo o mais completo (e talvez também o último) manual da época concentrado nas figuras de linguagem, está consciente dos autores que lhe antecederam e de sua necessidade de transformar a linguagem comum em algo trabalhado, burilado e novo, criando assim uma obra modelar, que tenta abarcar a totalidade dos ornati e sua aplicação nos textos clássicos e na Bíblia, algo que remete ao Renascimento como um todo, uma vez que "[...] estas crenças [renascentistas] interligadas - sobre a natureza social do homem, sobre a centralidade da língua para os intercâmbios humanos, sobre a habilidade do rétor para influenciar pessoas, sobre sua dedicação à verdade e à virtude - todo esse sistema tornou inevitável que toda a atenção voltasse-se para a elocutio, na forma da eloquência a serviço dos mais nobres ideais humanos, sendo as figuras de linguagem os melhores meios de realizá-la". ${ }^{76}$

Enquanto em Erasmo a eloquência depende das boas ideias para ser benéfica, em Peacham, posterior a Erasmo em décadas, as boas ideias só conseguem ser expressas com uma bela eloquência. Em sua carta dedicatória à John Puckering (1593), ele concorda com Cícero e com Erasmo, ao afirmar que "influenciar a elocução sem o discernimento da sabedoria é como manejar um mavioso instrumento musical sem conseguir fazê-lo soar"; $;{ }^{\prime 7}$ no entanto, sua preocupação, diferentemente daquela de Cícero e Erasmo, baseia-se exclusivamente na ornamentação da linguagem e a relação desta com as outras partes retóricas. A elocução, portanto, recebe sempre atenção e lugar privilegiados, o que faz com que a leitura dos textos clássicos tal como proposta por Erasmo seja transformada quase que exclusivamente numa busca por exemplos de tropos e figuras.

É impossível não perceber a distância entre as epístolas introdutórias de Peacham e os manuais em si. Tais epístolas acabam por seguir de perto a Erasmo, afirmando, por exemplo, que o estudo dos ornamentos é necessário e deve ser sempre complementado com a sabedoria, "para que a eloquência

${ }^{76}$ Vickers 2002, 285.

${ }_{77}$ "To affect eloquence without the discretion of wisdom, is, as to handle a sweete instrument of musicke without skill." 
torne-se sábia e a sapiência torne-se eloquente",78 já que "a sabedoria requer a luz da eloquência e a eloquência requer a fertilidade da sabedoria". ${ }^{79}$ Porém, se vários oradores, como Demóstenes, Cícero e Quintiliano “conseguiram atingir uma enorme excelência dentre seus iguais", ${ }^{80}$ isso se deu porque observaram "principalmente os ornamentos, com os quais a vida humana é embelezada e os louvores mais preciosos são encomendados" ${ }^{\prime 1}$ (epístola dedicatória da primeira edição a John Elmer, de 1577). Sendo assim, são as figuras de linguagem que devem delectare, docere e principalmente mouere, como sua aplicação no próprio manual o demonstra. As figuras de linguagem passam a ser a própria retórica e acabam por conseguir englobar escopos até mesmo da inuentio, dispositivo, memória. Desse modo, às figuras de linguagem é conferido todo o poder retórico, como se o uso dos ornati fosse suficiente para alcançar a primordial necessidade retórica: persuadir. E há figuras para qualquer nuance da linguagem que se deseje, até mesmo porque, em um universo com 227 figuras, difícil é não utilizá-las. O que se deseja é que tal uso seja o melhor.

A importância dos ornamentos torna-se central, uma vez que eles poderiam transformar um discurso cru ou comum em uma fala persuasiva e até mesmo artística. E isso é o suficiente. Assim, aquilo que é mais propriamente relativo à inuentio vai perdendo terreno para a ornamentação.

Segundo Peacham, "uma figura de linguagem é uma forma das palavras, orações ou sentenças, recém criada pela arte, que diverge da maneira vulgar e costumeira de escrever ou falar". ${ }^{22}$ Essas figuras, em si mesmas, conseguem persuadir uma plateia, algo que Erasmo não teria afirmado. Mas um comentário de Gray ${ }^{83}$ acerca dessa questão explica que, para os oradores humanistas, sem a eloquência, aqui já grandemente assimilada pelo emprego do ornamento, "a verdade manter-se-ia calada, o conhecimento nunca serviria à realidade dos assuntos humanos ou falaria às necessidades da existência mundana." Sem a eloquência, ainda, "as outras artes se perderiam, a sociedade organizar-se-ia de modo ruim; a justiça poderia não triunfar e o mal não seria destruído". Por detrás da afirmação de que man-

${ }^{78}$ Da epístola dedicatória a John Elmer (1577): "that [...] Eloquence maye by wise, and [...] wisedome eloquent."

${ }^{79}$ Da epístola dedicatória a John Elmer (1577): "wisedome doe requyre the lighte of Eloquence, and Eloquence the fertility of Wysedome."

80 "Have attayned to a great excelency in their kinde."

81 "The onelye Ornamentes, whereby mannes lyfe is bewtifyed, and a prayse moste precyous purchased."

82 "A figure is a forme of words, oration, or sentence, made new by art, differing from the ulgar maner and costome of writing or speaking" (conforme a segunda edição, de 1593).

${ }^{83}$ Gray 1963, 504. 
ter-se na elocução era suficiente, portanto, oculta-se a concepção de que a verdade, a justiça e os demais valores deveriam ter uma vestimenta à altura de sua bela essência.

Assim, o De Copia, texto que influenciou os experimentos literários de Rabelais, Ronsard e Montaigne, ${ }^{84}$ não deixou de ser, para uma grande parte dos estudantes, e cada vez mais, uma licença para preocupar-se quase que exclusivamente com a linguagem, mais do que com os temas. Mas se a proposta de Erasmo não se impôs senão parcialmente, sua vitória na educação foi cabal.

A defesa de uma educação completa, baseada nos estudos clássicos, sem excluir o mundo cristão, é praticamente sinônimo daquilo que compreendemos hoje como "renascentista" e "humanista". Seus escritos, todos em latim, foram centrais para a educação europeia como um todo, sendo que "Erasmo não foi o professor de um país, como Melanchthon, que é lembrado até hoje como Praeceptor Germaniae, mas de toda a cristandade, seja católica ou protestante", ${ }^{\prime 5}$ tendo conseguido reconciliar e unir as litterae humanae às litterae sacrae ${ }^{86}$ e, com isso, transformar-se no símbolo mais acabado de humanista que o século xvi produziu.

Símbolo de toda uma época, Erasmo morreu em 1536, duas décadas antes de toda a sua obra fosse colocada no Index Librorum Prohibitorum da Igreja católica.

\section{CONCLUSÃO}

Em sua imensa obra, Erasmo manteve sempre uma posição conciliatória acerca da convivência dos textos clássicos com os cristãos. Isso significava, naquele momento, defender o estudo tanto de textos filosóficos e literários quanto, por outro lado, o daqueles que se apresentavam como revelados e portadores da Verdade. Por isso, Erasmo esteve frequentemente envolvido em polêmicas. Uma, contra aqueles a quem chamou barbari, que eram aqueles que simplesmente deixavam de lado a tradição da Antiguidade por ser pagã; contra os indocte docti, os semiletrados, que não conheciam senão rudimentos das línguas antigas, embora recorressem a Aristóteles até mesmo para explicar questões bíblicas; e contra os ciceroniani, os quais, entendendo a imitação de forma literal, faziam questão de usar apenas aquelas palavras, formas fra-

\footnotetext{
${ }^{84}$ Mack 2011, 87.

${ }_{85}$ Caspari 1947, 92.

${ }^{86}$ Idem, 87.
} 
sais e figuras de linguagem encontradas no orador romano, mesmo que isso significasse a produção de textos absolutamente artificiais e ineficazes. Em seu De Copia, Erasmo propões formas de adquirir abundância para melhor expressar-se, sempre considerando temas e palavras em conjunto e levando-se em conta a situação discursiva, o público ouvinte, as circunstâncias etc. Com isso, a obra é dupla, dividindo-se entre uerba e res, elocutio e inuentio. Esse livro obteve um sucesso extraordinário e, se não inaugurou, estimulou decisivamente a produção de manuais de figuras de linguagem. Estes, entretanto, em maior ou menor medida utilizam Erasmo exatamente para aquilo que ele não preceitua, ou seja, uma prática da retórica que se confunde com a ornamentação das figuras de linguagem, tendência adotada já pelos primeiros humanistas e sempre presente pelos séculos XV e XVI.

Entre os livros que se originaram diretamente do De Copia, mas caminharam em direção oposta àquela proposta por Erasmo, ressaltamos especialmente o manual The Garden of Eloquence, de 1577.

\section{REFERÊNCIAS}

Allen, P. S., ed. 1906. Opus Epistolarum Des. Erasmi Roterodami. Oxford: Oxford Universiy Press.

Baldwin, C. S. 1928. Medieval Rhetoric and Poetic (to 1400) - interpreted from representative works. New York: The Macmillian Company.

Caspari, F. 1947. "Erasmus on the social functions of Christian Humanism." Journal of the History of Ideas 8.1. University of Pennsylvania Press.

Chomarat, J. 1981. Grammaire et Rhetorique chez Erasme. Les Classiques de l'Humanisme. Paris: Les Belles Lettres.

Erasmo, Desidério. 2013. Diálogo Ciceroniano. Trad., ed. e notas Elaine C. Sartorelli. São Paulo: Unesp.

Gray, H. H. 1963. "Renaissance Humanism: The Pursuit of Eloquence." Journal of the History of Ideas 24.4. University of Pennsylvania Press.

Kristeller, P. O. 1990. Renaissance Thoughts and the Arts - Collected Essays. Princeton: Princeton University Press.

Mack, P. 2011. A History of Renaissance Rhetoric 1380-1620. New York: Oxford University Press.

Mack, P. 1993. Renaissance Argument: Valla and Agricola in the tradition of Rhetoric and Dialectic. Leiden; New York; Köln: Brill.

Matheson, P. 1998. The Rhetoric of the Reformation. Edinburgh: T\&T Clark.

Mesnard, P. 1970. Erasme. La Philosophie Chretienne. Paris: Ed. Vrin.

Millet, O. 1992. Calvin et la dynamique de la parole. Etude de Rhétorique Réformée. Paris: Librairie Honoré Champion. 
Scott, I. 1910. Controversies over the imitation of Cicero as a model for style and some phases of their influence on the schools of Renaissance. Bibliolife (reproduction - 2009).

Sloane, T. O. 1991. "Schoolbooks and rhetoric: Erasmus's Copia." Rhetorica: a Journal of the History of Rhetoric 9.2. University of Califoria Press.

Sowards, J. K. 1958. "Erasmus and the apologetic textbook: a study of the De Duplici Copia Verborum ac Rerum." Studies in Philology 55.2. University of North Carolina Press.

Vickers, B. 2002. In Defense of Rhetoric. Oxford: Clarendon Press.

\section{*}

Abstract. This paper intends to comment the importance and the permanence of Classical Antiquity authors in the work of Erasmus of Rotterdam, who has always been aware of the issues of coexistence between ancient literature and Christian values. Erasmus, who had never abandoned the defense of biblical studies, also defended, on the other hand, the acquisition of a profound knowledge of Classical writers. In the context of Christian literature, in which ideally rude words must be able to express sublime truths, this issue is also the scenario for discussions about the role of eloquence, in an era in which religious polemics increasingly questioned the ars, as, at the same time, they forced it to find new practices. This subject permeates all of Erasmus' works and it has been the centre of several polemics he found himself engaged, either against the barbari (those who despise Antiquity) or against the ciceroniani (those who imitate Cicero alone and despise the so-called plain Christian style).

Keywords. Renaissance, Rhetoric, Erasmus, Classical Antiquity, Christianity. 